studied neologisms has been introduced as there is not their translation into Ukrainian yet; examples of their use in modern English-language publications have been represented.

The changes in construction and design creativity transforming into new styles in architecture, the influence of modern man's aspirations on the arrangement of his own home, and, accordingly, changes in the lexical composition of the language due to the need for a new nomination have been analyzed. A statistical analysis of neologisms according to the method of formation has been conducted, in the result compounding and telescopy were singled out as the most productive ways of forming neologisms of the concept "HOUSING". The main reasons for the emergence of new words have been identified: new nomination objects, linguistic economy, and word play.

The need to describe the cognitive foundations of new words has been substantiated; the purposes of their use in language, and, most importantly, the need to study the natural relationships between changes occurring in society and the constant updating of the lexical system have been emphasized.

Key words: neologism, concept, cognitive linguistics, verbalization, housing.

DOI: https://doi.org/10.32782/2410-0927-2020-12-14

УДК $811.112 .2 ’ 36$

Софія Застровська, Олександр Застровський

\title{
ОСНОВНІ ХАРАКТЕРИСТИКИ ФАЗОВОЇ СТРУКТУРИ ДІАЛОГІЧНОГО ДИСКУРСУ
}

Стаття присвячена виявленню характерних ознак фазової організації діалогічного дискурсу. Ретельно розглянуто трактування релевантних для досягнення мети і завдань даного дослідження таких понять, як Gespräch, Dialog, Konversation, Diskurs. Зазначено їхні спільні та відмінні ознаки згідно з науковими традиціями, характерними для сучасної лінгвістики. Пофазовий аналіз діалогічного дискурсу дозволив виявити як основні ознаки, так і різні чинники, що впливають на його процес. Початкова (контактовстановлювальна) та кінцева (контакторозмикаюча) фази здебільшого ритуалізовані, при цьому допускають варіативність свого мовного й немовного оформлення особливо при зіставленні телефонної та face-to-face комунікації. Варіативність залежить насамперед від соціального статусу, ситуативної ролі комунікантів, а також психологічних, когнітивних, семантико-прагматичних чинників, які впливають на успішність/неуспішність інтеракції співрозмовників. Ядерна фаза діалогічного дискурсу демонструє тематику розмов, мотиви, установки цілей комунікантів, уживані ними комунікативні ходи (мовленнєві акти) та лексико-граматичні засоби їхнього вираження. Семантико-тематичні ознаки ядерної фази діалогічного дискурсу зумовлені пропозиційним змістом. При цьому домінантну роль відіграє пропозиційний предикат, виражений дієсловом відповідної семантики в граматичних формах Indikativ чи Konjunktiv, що залежить від типу мовленнєвих актів у комунікативних ходах інтерактантів.

Тип уживаних синтаксичних структур засвідчує експліцитність та імпліцитність вираження мовленнєвих актів. Аналіз емпіричного матеріалу доводить існування немовного вираження контактовстановлення та контакторозмикання у фазовій структурі діалогічного дискурсу. Ядерна фаза (особливо у творах художньої літератури) може бути ускладненою, де різні фази діалогічного дискурсу перехрещуються, повторюються. Аналіз таких дискурсів зумовлює залучення до трактування дискурсу понять із різних традицій його дослідження.

Ключові слова: діалогічний дискурс, фазова організація, семантико-тематичний, комунікативнопрагматичний, лексико-граматичний, мовний/немовний/парамовний.

Вступ. У системі німецької мови існують взаємопов'язані , на нашу думку, терміни; 3 одного боку, вони демонструють синонімічність, як показує аналіз лексикографічних джерел $[14,15]$, а з іншого, спільні та відмінні ознаки, як зазначається в наукових розвідках $[5,10]$ та ін. У сучасній лінгвістиці дослідження розмови піднесено на новий рівень - рівень дискурсу, i проблема розмежування наведених понять ще більше ускладнюється. У межах даної статті зупинимось на діалогічному дискурсі, його фазовій організації, яка включає: а) початкову фазу (контактовстановлювальну); б) ядерну фазу, що характеризується семантико-тематичними та комунікативно-прагматичними ознаками; в) кінцеву фазу (контакторозмикаючу). Найбільш дослідженими на сьогоднішній день $є$ початкова і кінцева фази. Недостатньо дослідженою $є$ ядерна фаза [5, с. 91-105].

Актуальність даної розвідки зумовлена недостатнім, проте необхідним для успішної комунікації, рівнем дослідження діалогічного дискурсу з урахуванням його фазової організації, мовних, немовних та парамовних чинників впливу на досягнення намірів та цілей співрозмовників.

(C) Застровська С., Застровський О., 2020 
Метою роботи є дослідити на матеріалі німецької мови фазову організацію діалогічного дискурсу в різних дискурсивних ситуаціях.

Мета роботи зумовила такі завдання: 3'ясувати трактування релевантних для нашого дослідження понять Gespräch, Dialog, Konversation, Diskurs; проаналізувати фрагменти діалогів та виявити впливові пофазові чинники успішної комунікації.

Об’єкт дослідження - мовні, немовні та фрагментарно парамовні засоби актуалізації інтенції співрозмовників на предмет їхньої релевантності для репрезентації різних фаз діалогічного дискурсу. Емпіричним матеріалом обрано наведені розмови у творах сучасної німецької літератури, а також запис спонтанних діалогів у повсякденній комунікації представників німецької спільноти різних вікових груп, здійснених Вернером і Алісою Байле [2].

Методи та методики дослідження. У роботі застосовані загальнонаукові методи: індукція, дедукція, аналіз, синтез - для уточнення теоретичних засад дослідження, формулювання висновків та їхнього обгрунтування; спеціальні (лінгвістичні) методи: метод словникових дефініцій - для з'ясування релевантних для дослідження понять; інтерпретаційний аналіз - для аналізу й інтерпретації емпіричного матеріалу; інтент-аналіз - для встановлення намірів i цілей комунікантів; семантичний аналіз для 3'ясування тематики діалогічного дискурсу. На кожному етапі дослідження застосовано комплексну методику.

Результати та дискусії. Перш ніж приступити до виявлення характерних ознак фазової організації німецькомовного діалогічного дискурсу, вважаємо релевантним звернути увагу на поняття, які стали підгрунтям даної сфери наукового дослідження. Це такі поняття, як Gespräch, Dialog, Konversation. У двомовному словнику В. Мюллера лексема Gespräch перекладена так: розмова, бесіда; переважно у множині дискусія, діалог, нарада [14, с. 282]. В одномовному німецькому словнику G. Wahrig лема слова Gespräch містить багатовимірне трактування, а саме: 1) за суттю: mehrmaliger oder längerer Wechsel (багаторазовий чи тривалий обмін промовами (тут i далі переклад наш: С. 3. та О. 3.); Rede und Gegenrede (промова і промова у відповідь - діалог); Unterhaltung (бесіда, розмова); Dialog (Zwiedialog) (діалог між двома); öffentlich Besprochenes (публічно обговорюване); Gegenstand öffentl. Geredes (Stadt -, Tages -) (предмет публічної балаканини / міські плітки чи головна тема дня); 2) за засобом зв'язку, частотою розмов i віддаленістю: einmalige telefonische Zwiesprache (одноразовий телефонний діалог); Blitz-, Fern-, Orts- (термінова телефонна розмова, міжміська, місцева); 3) за діями співрозмовників стосовно розмови: das Gespräch abbrechen (припиняти), unterbrechen (перервати), abnehmen (знімати слухавку), anmelden (замовляти телефонну розмову); wieder aufnehmen (поновити перервану бесіду), führen (вести розмову), 4) за ціною: kosten (розмова коштує); 5) за втручанням третіх осіб: vermitteln (бути посередником), abhören (підслуховувати), belauschen (підслухувати, підглядати таємно, спостерігати); 6) типологія розмов: а) за соціальним статусом чи ситуативною роллю співрозмовників: dienstliches (службова розмова) fachliches (фахова), freundschaftliches (дружня); politisches (політична); б) за терміновістю: dringendes (термінова); в) за оцінним ставленням: ernstes (серйозна); heiteres (весела); interessantes (цікава); г) за формальністю: zwangloses (невимушена); г) за тривалістю: kurzes (коротка); langes (довга) [15, с. 357]. Якщо додати ще одну цитату із Wahrig, то лексеми Gespräch і Dialog трактуються як синоніми: Dialog - Gespräch zw. zweien oder mehreren, Wechselrede (Dialog - це розмова (Gespräch) між двома чи декількома особами; обмін промовами [15, с. 357]. Цей синонімічний зв'язок підсилюється і походженням слова Dialog: (grch. Dialoges “Zwiegespräch”) (з грецької: dialog “розмова між двома"). Ми приділили трактуванню значень лексем Gespräch та Dialog стільки уваги через те, що в наукових розвідках наведені аргументи на їхню відмінність. Аналізуючи ядерне значення лексеми Gespräch за словниками Klappenbach/Steinitz та Duden німецькі дослідники K. Brinker та S.F. Sager підсумовують, що поняття розмови Gespräch визначається за такими критеріями: - щонайменше два інтерактанти; міна ходів; - усна реалізація; - скерованість на визначну тему [5, с. 11].

У повсякденній мові вживаються слова Dialog та Konversation. Проте вони мають, як стверджують дослідники, більш вузьке значення ніж слово Gespräch. Лексема Dialog означає серйознішу розмову на значущу тему. Konversation - більш конвенційна, поверхнева i невимушена розмова (Unterhaltung) (принаймні у німецькомовному середовищі). Отож, 
Gespräch за значенням нейтральніше, ніж Dialog і Konversation [5, S.11]. Тим не менше, на основі проведеного аналізу на даному етапі ми доходимо висновку, що, як би там не було, i Gespräch i Dialog є синонімами, хоча ми і свідомі того, що навіть синоніми не є дублетами. Що ж до Konversation, то це ніби намір наголосити близькість до анг. лексеми conversation, хоча conversation у англо-американському середовищі має свої відмінні ознаки. Неоднозначність трактування нім. Konversation і Konversationanalyse та анг. conversation і conversation analysis стає особливо виразною при порівнянні їхнього вживання в німецькомовному та англоамериканському середовищах та при перекладі з німецької мови на англійську [10, с. 247-250]. Суперечки навколо діалогу, як мистецтва ведення розмови розпочалися ще за часів класичної давнини (див. огляд [3, с. 4-16] у період зародження загального мовознавства. Не зникають вони і тепер, а в період поширення нової наукової парадигми (когнітивно-дискурсивної) обростають новими ідеями й об'єктом наукових пошуків стає діалогічний дискурс, виявлення характерних ознак якого ми й обрали темою нашої статті.

Дискурс, як наголошує харківська дослідниця Л. Р. Безугла, є одним із найбільш неоднозначних понять у сучасній лінгвістиці [4, с. 73]. Базуючись на прийнятому в Харківській лінгвістичній школі [9] визначенні дискурсу, Л. Р. Безугла в окремих позиціях модифікує його і дає таке трактування: дискурс - “сукупність процесу й результату мисленнєво-комунікативної діяльності мовців у широкому (онтологічному, когнітивному, комунікативному, психологічному, соціокультурному) контексті. Антропоцентричність дискурсу означає зосередження на мовцях як суб'єктах комунікації та зумовлює вивчення не тільки лінгвального аспекту дискурсу (мовленнєвої діяльності комунікантів і тексту), але й позалінгвального (когнітивної, комунікативної діяльності та дискурсивного контексту)" [4, с. 73]. Окрім наведеного визначення, на сьогоднішній день поширеними $\epsilon$ інші трактування дискурсу (див. огляд [13, с. 11-58]. Наведемо окремі із них: дискурс як ідеологія панівної влади в дусі М. Фуко, а також дискурс як сукупність тематично співвіднесених текстів (огляд: [7, с. 103-118]. Мішель Фуко розвиває своє розуміння дискурсу в філософському плані. Панування над дискурсом означає владу, оскільки “Дискурс - це не просто те, що переводить боротьбу (...) у мову: він $\epsilon$ те, за що і чим ведеться боротьба; він є влада, якою прагнуть заволодіти" (цит. за [10, с. 247]). Diskurs у розумінні М. Фуко може матеріалізуватись у різний спосіб (у текстах і спорудах) (там само).

Інше філософське розуміння дискурсу в німецькомовному середовищі розвиває Ю. Хабермас. Своє трактування вільного від панування дискурсу він пов'язує 3 ідеальною мовленнєвою ситуацією і раціональною суспільною діяльністю. Подібні міркування характерні і для Х. П. Грайса. На його думку, взаємне порозуміння комунікантів можливе лише при дотриманні принципів кооперації [10, с. 248].

За визначенням В. Е. Чернявської (як розвиток ідеї М. Фуко) дискурс - це система обмежень, які висуваються до потенційних висловлень в силу певної соціальної, ідеологічної, у тому числі і наукової позиції ‘...>. Дискурс пропонує такі, а не інші стандарти комунікативномовленнєвої поведінки окремих особистостей у типових ситуаціях. Влада дискурсу означає можливість широкого соціального управління й маніпулювання, коли в особливий спосіб “каналізуються" теорії, ідеї, оцінки, погляди, судження, посткомунікативні дії різних суб'єктів/колективів 〈...〉 [7, с. 133].

Трактування дискурсу в дусі М. Фуко подає А. ван Дейк [8, с. 8-35] як ідеології панівної влади - домінування над світосприйняттям, над дискурсом, свідомістю, соціально-дискурсивними практиками. Подаючи визначення влади, ван Дейк, на нашу думку, розширює це поняття, оскільки наголошує на тому, що владну силу мають уряди, парламенти, державні організації, військові, бізнес-корпорації, а також представники деяких професій, наприклад, лікарі, професори або ж такі соціальні ролі, як батьки 〈...>. Владу слід визначати не як владу індивіда, а як владу соціальної позиції і як складову влади організації [8, с. 30]. Ван Дейк загострює увагу також на ще одній сфері “символьної влади” - освіті. Наведемо цитату: "Ми знаємо, що вчителі й підручники впливають на свідомість студентів, і ми навряд чи станемо заперечувати, що очікуємо від них такого впливу, якщо ми хочемо, щоб наші діти чомусь навчились. Проте досить складно відрізнити навчання, що допомагає студентам у їхньому теперішньому і майбутньому 
житті від ідеологічного маніпулювання владних груп чи організацій i, відповідно, від упередження щодо розвитку в студентів критичного потенціалу” [8, с. 30]. I далі: ‘...> сьогодні символічні еліти - політики, журналісти, вчителі, адвокати, чиновники і всі, хто має доступ до публічного дискурсу, чи бізнес-менеджери, які керують цим доступом (наприклад, як власники масс-медійних імперій) - всі вони є ті, кого слід назвати владними групами, оскільки вони відповідають цьому критерію (тобто мають доступ до публічного дискурсу чи контролю над ним [8, с. 32].

У якій саме традиції проводити аналіз будь-якого дискурсу, залежить від дослідника, його намірів, установок, мети і завдань, що зумовлюють як підбір, так і аналіз та інтерпретацію емпіричного матеріалу. Але не можна сказати, що різні трактування дискурсу абсолютно не пересікаються. Вони залежать від аспекту, обраного домінувальним при дослідженні такого складного багатоаспектного феномену як дискурс. Це доводить і емпіричний матеріал. В одних випадках, обравши певний аспект аналізу, можна повністю абстрагуватись від інших. А в інших інтерпретація ускладнюється тим, що необхідно залучати до аналізу і поняття, домінувальними для іншої традиції чи іншого трактування дискурсу. Звернемось до емпіричного матеріалу.

1. Контактовстановлювальна фаза діалогічного дискурсу. Варіативність уживання мовного чи немовного матеріалу залежить від соціального статусу та ситуативної ролі комунікантів дискурсивної ситуації. Контактовстановлювальна (початкова) фаза діалогічного дискурсу ритуалізована i проходить за певним сценарієм, що зумовлює послідовність інтеракційних дій (ходів) комунікантів. Основними ходами при цьому $є \pm G r u \beta$ (вітання), \pm Gegengruß (вітання у відповідь), \pm Identifikation (представлення/ідентифікація). При цьому не всі вони присутні в початковій фазі (на що вказують символи \pm ). Це залежить від багатьох чинників. Насамперед слід зазначити, що відмінність спостерігається, якщо порівняти розмови телефонні та face-to-face; ступінь знайомства співрозмовників; їхні статусно-рольові відносини. У face-toface спілкуванні важливими $є$ випадковість чи запланованість зустрічі та інші фактори. Безперечно, що в телефонній розмові важливу роль відіграють мовні засоби спілкування, але не слід ігнорувати й парамовні, коли за тембром/силою голосу можна розпізнати психологічний стан співрозмовника - його роздратованість, налаштованість/неналаштованість вести розмову, що чинить вплив і на вживання мовних засобів. Що стосується мовних засобів, то вживаним $\epsilon$ hallo, ja. Окрім того, з голосу ми впізнаємо знайому людину, що усуває процедуру ідентифікації. У телефонній розмові контактовстановлальна фаза розпочинається, коли, почувши телефонний сигнал, ми знімаємо слухавку і продовжується (причому не обов'язково з уживанням часток hallo i ja) з ідентифікацією і привітанням, наприклад:

№ 1. Doktor Braun: Doktor Braun. Guten Abend.

Karin: Karin Ridder, guten Abend, Herr Doktor Braun. Ich rufe ... (W. und F. Beile, c. 27) Відповідь після зняття телефонної трубки: ідентифікація+вітання - ідентифікація + вітання + звертання.

№ 2. При звертанні до групи, лектор DAAD Андре Бьом, який працює у нас на кафедрі, звертається так:

Andre: Hallo zusammen! Kennt jemand ... (і далі перехід до ядерної фази). Ідентифікація співрозмовника, як члена групи, здійснюється автоматично.

Телефонні розмови зазвичай короткі. Розмови face-to-face відрізняються іншими мовними/немовними/парамовними засобами, хоча вони також ритуалізовані. Під впливом різних позамовних чинників вони демонструють варіативність уживання, наприклад:

№ 3. Давно знайомі Ulrike та Heidi випадково зустрічаються.

Ulrike: Hey, hallo, was machst du denn hier?

Heidi: Mensch, dich hab' ich ja ewig nicht mehr gesehen.

Ulrike: Du, ich dich auch nicht, wie geht's dir denn so?

Heidi: Och, grad' ganz gut, aber gut siehst du aus.

Ulrike: Ja, du auch. Ach ich freu' mich echt, daß ich dich mal wiedersehe.

Heidi: Das find' ich ja toll, daß wir jetzt ... so ein Zufall. «...> (W. und A. Beile, c. 21).

Випадкова зустріч, невимушена розмова, про що свідчать і звертання на ти, і вживання 
часток, вигуків Och, Ach, фамільярне Mensch і стандартні фрази ,dich hab ich ja ewig nicht mehr gesehen (я тебе вже вічність не бачив) та штамп wie geht's dir (як поживаєш), на який ніхто не чекає докладної відповіді, принаймні в початковій фазі розмови, емоційна позитивно оцінна лексика (toll, freuh' mich), комплімент (gut aussehen) засвідчують радість від неочікуваної зустрічі.

У ситуаціях, коли потрібно звернутись до незнайомих людей на вулиці, щоб отримати потрібну інформацію, контакт розпочинається з вибачення (Entschuldige bitte, kannst du mir sagen ...<...); або Entschuldigen Sie bitte, können Sie mir sagen, ...<...> (W. und A. Beile, S. 100; 101). Звертання на ти чи Ви залежить від віку людини, до якої звертаються. Інколи вживається вітання (Guten Tag!) чи прикладка (mein Herr):

№ 4. Entschuldigen Sie, mein Herr, könnten sie mir 〈...〉 (W. und A. Beile, c. 103).

№ 5. Або: Äh, guten Tag, können Sie mir sagen ... 〈...〉 (W. und A. Beile, c. 102). Ввічливість демонструється вживанням модального дієслова кӧnnen в Indikativ або Konjunktiv, 士лексема ввічливості bitte.

У телефонних розмовах при дзвінках у державні установи зазвичай ідентифікується установа чи номер іiі телефона:

№ 6. Beamter: Reiseauskunft. Iserlohn, guten Tag (W. und A. Beile, c. 113).

При персональній ідентифікації співрозмовників інколи виникають конфузні ситуації. Як приклад наведемо початкову фазу телефонної розмови із твору Fünf tote alte Damen von Hans Gruhl. Автор твору в трагічну історію вводить елементи гумору: молода дівчина на прізвище Groß телефонує до лікаря приватної практики на прізвище Klein за оголошенням: лікареві потрібна нова медична сестра.

№ 7. Доктор Klein уже збирався залишити клініку, як дзвонить телефон. Він підняв слухавку.

"Klein", sagte ich.

"Hier ist Groß”, sagte eine Stimme. «...〉. Ich überlegte, wer von meinen Bekannten wieder einen dummen Witz mit mir machen wollte.

"Hahaha", machte ich.

"Was soll das?" fragte sie.

"ich habe schon bessere Witze gehört", sagte ich matt. "Bist du es, Inge?"

"Nein, ich bin nicht Inge". Sie schon leicht empört. "ich heiße Groß-Sie haben doch annonciert wegen einer Sprechstundenhilfe. - sind Sie das nicht?"

"ich bin es 〈...)" (W. und A. Beile, S. 19).

У наведеному фрагменті виникло непорозуміння через антоніми Klein - Groß. I контактовстановлювальна фаза продовжилась у часі, аж доки не з'ясувались додаткові обставини.

Звернемо увагу на немовний спосіб встановлення контакту. Ритуалізований спосіб, яким користуються переважно чоловіки, - це рукостискання з мовним чи без мовного супроводу. Однак інколи в нестандартних ситуаціях комуніканти вдаються також до нестандартних дій. Наведемо приклад такої ситуації, але не повністю, оскільки в автора їі опис займає майже цілу сторінку. Обмежимося лише короткою передачею ії змісту:

№ 8. Арно після неочікуваної телефонної розмови зі своїм шефом мусив розбудити свою молоду дружину Люсі, яка після святкування їхнього одруження глибоко спала. Окрім втоми, Люсі мала ще й сонну хворобу (Schlafkrankheit). Із власного досвіду Арно знав, що іiі розбудити буде важко. Але, щоб розповісти їй про зміну їхніх планів, потрібно було спочатку налагодити 3 нею контакт. Він перепробував все, але врешті-решт вилив на неї пів відра холодної води. І лише повернувши іiі до тями, він повідомив про стан справ (Backhaus, S. 20).

Отже, як бачимо, на успішність початкової фази діалогічного дискурсу впливають різні мовні, парамовні та немовні фактори.

2. Ядерна фаза діалогічного дискурсу. Після встановлення контакту адресант відразу переходить до ядерної фази, яка характеризується семантико-тематичними, комунікативнопрагматичними та синтаксичними ознаками [5, с. 58]. Як засвідчує семантичний аналіз, тематика розмов є різноманітною. Короткі телефонні чи face-to-face розмови торкаються здебільшого прийнятих у суспільстві етикетних норм соціальної взаємодії, що засвідчене лексикограматичним матеріалом. Це такі теми, як значущі події в житті співрозмовників (ювілеї, 
закінчення учбового закладу, дні народження, укладання шлюбу, кар'єрний ріст, завершення екзаменаційної сесії, тощо); плани на майбутнє; здійснення покупок; пошук місця працевлаштування; справи у сім'ї; виховання дітей; орієнтація в чужому місці; німецька пунктуальність; святкування вихідних днів; прийом гостей тощо.

Наведемо приклад:

№ 9. Claudia: Hast du heute abend was vor?

Andrea: Heute abend ... nein, heute abend noch nicht, warum?

Claudia: Ach, das trifft sich gut. Wenn du Zeit hast, kannst du zu mir kommen, weil meine Eltern sind nicht da, und da dacht' ich, wir könnten uns'n gemütlichen Abend machen.

Andrea: Ja, das ist gut. Heute abend kommt'n Krimi, dann könnten wir uns den zusammen angucken. Ich hab' bestimmt wieder Angst alleine.

Claudia: Ja, ist' gut, machen wir (W. und A. Beile, c. 47).

Семантичний аналіз і інтент-аналіз кооперують. Макротему даного діалогу можна кваліфікувати як «Проведення затишної вечірки». Про це свідчить пропозиційний зміст (gemütlichen Abend zusammen machen). Мікротемою $1 €$ «Перегляд кримінального фільму» (Krimi nur zusammen angucken). Інтент-аналіз дозволяє з'ясувати інтенцію Клаудії, яка втілюється в іiі мовленнєвих актах запрошення на вечірку, що знаходить вираження у відповідних синтаксичних структурах: kannst du zu mir kommen. Wir könnten uns gemütlichen Abend machen. Мікротема 2: «Відсутність батьків» (Meine Eltern sind nicht da). Це є, на нашу думку, аргументація бажання влаштувати затишну вечірку за відсутності батьків. Мовленнєвий акт запрошення виражений головним реченням складнопідрядного умовного з уживанням модального дієслова kӧnnеn у розповідній формі Indikativ (kannst du zu mir kommen). Фактично це імпліцитна форма вираження мовленнєвого акта запрошення. Послідовність мовленнєвих ходів: запрошення - згода (ja, das ist $g u t)+$ аргументація щодо перегляду кримінального фільму (Ich hab bestimmt wieder Angst alleine.)

Звернемо увагу ще на одну дискурсивну ситуацію, у якій, на наш погляд, переплітаються різні фази діалогічного дискурсу. Це телефонна розмова між відомим нам уже Арно (приклад № 8) та його шефом (наведемо фрагменти розмови).

№ 10. Das Telefon hörte nicht auf zu klingeln. Bis es Arno zu dumm wurde. Er hüpfte aus dem Bett, lief ins Arbeitszimmer und hob den Hörer ab. Wie gewöhnlich meldete er sich nur mit seiner Nummer.

"Ist dort Herr Arno Otto?"

"Am Apparat". ‘...〉

"Hier spricht Protasius Schmitt."

Der Schef!

"Gute Nacht, Herr Schmitt - äh - ich wollte sagen: guten Abend."

"Störe ich?"

"Nein ... nicht direkt ..."

"Ich weiß. Sie haben heute geheiratet. Es tut mir leid."

‘...〉,, Wieso tut Ihnen das leid?"

"Ich meine, daß ich Sie störe, tut mir leid. Aber es muß sein." (...)

Also, passen Sie Obacht!'”(...>

"Sie müssen morgen früh nach Venedig fliegen."

Arno schwieg.

"Haben Sie verstanden? Sie müssen morgen früh nach Venedig fliegen. Hallo ...?"

"Ja", sagte Arno grimmig.

"Also passen Sie Obacht: ‘...〉

(...) Arno schwieg.

Hallo! ... Hallo! ... Haben Sie verstanden?”

〈...〉 (Backhaus, c. 17-19).

Протягом розмови Protasius Schmitt тричі повторював “Passen Sie Obacht!”, п’ять разів “Haben Sie verstanden?”, неодноразово перевіряв наявність контакту (“Hallo! Hallo!”). Не тому, що був поганий зв’язок, а тому що, Arno був приголомшений цим телефонним дзвінком і взагалі 
розмовою за обставин, які склалися (і все це в шлюбну ніч!).

Початкова фаза діалогу відповідає ритуалізованому зразку: Арно піднімає слухавку+ідентифікація+привітання. Макротема ядерної фази: «Службове термінове відрядження». Макротема розгортається у мікротемах: 1) «Виліт ранішнім рейсом до Венеції»; 2) «Зустріч з Andria Musskatt»; 3) «Контракт з продуцентом нового продукту»; 4) «Зустріч біля довідкового бюро». Розмова ведеться у форматі Дорослий - дитина (багаторазові повтори метаелементів: Haben Sie verstanden? Ist Ihnen das klar?). Вживаються директивні мовленнєві акти, виражені наказовими реченнями; Imperativ та його конкурентні форми (модальні дієслова müssen, sollen). Нарешті, кінцева фаза розмови, клішована:

"Auf Wiedersehen, - Auf Wiedersehen, Herr Schmitt".

I тут знову: Hallo! Hallo!

"Ja?"

"Am Informationsschalter!"

“Jawohl, Herr Schmitt.” (Backhaus, c. 17-19)

Це фактично розмова 3 представником владної структури, який у жодному разі не сприйме будь-яку відмову. До цієї дискурсивної ситуації залучені різні фактори: фонові знання (Арно добре знає характер шефа), психологічний стан самого Арно, інтереси фірми та загроза втратити роботу тощо). Це сукупність факторів, які впливають на людину з одного боку, а 3 іншого - уможливлюють представникам владних структур чинити вплив на підлеглих. А це і $\epsilon$ у філософській традиції влада дискурсу і влада над дискурсом.

3. Кінцева (контакторозмикаюча) фаза. Ця фаза характеризується, як і початкова, ритуалізованістю. Тут уживаються мовні засоби прощання (auf Wiedersehen, bis bald, bis nächste Woche, Tschüs), комплімент і подяка за прийом (und es war unheimlich toll bei euch; ...und wir wollten uns nochmal herzlich für Ihre Einladung bedanken... Es hat uns wirklich unheimlich gut bei Ihnen gefallen); запрошення і обіцянка на подальші зустрічі (Wann sehen wir uns wieder?... Das Haus ist immer offen, kannst kommen, wann du willst; ... Wir werden uns bemühen, daß wir wieder kommen ...). Господарі, жалкуючи, що гості залишають їх, перепитують, чи дійсно вони вже мають йти, можуть пропонувати щось випити (Müssen Sie jetzt schon gehen?... Und es geht wirklich nicht, daß ihr noch ein Glas trinkt?...). Гості зазвичай називають причину, чому саме вони вже мають йти (... sonst verpasse ich meinen Bus...; Wir würden unheimlich gerne dableiben, aber die Kleine halt, und das ist klar...). У принципі, все це нагадує і нашу дійсність. Прощання може супроводжуватись і немовними діями: обіймами, поцілунками, рукостисканням тощо (всі приклади для демонстрації кінцевої фази взято із записів (W. und A. Beile, c. 37-43).

У телефонних розмовах актуалізуються такі мовленнєві акти, що і в face-to-face спілкуванні, за винятком дій, які неможливо вчинити по телефону. Правда, у віртуальному дискурсі завдяки новим технологіям використовуються різного роду смайлики, графічні знаки тощо.

Висновки. Проведений аналіз лексикографічних джерел, теоретичних праць, емпіричного матеріалу доводить наявність спірних питань при дослідженні дискурсу, у тому числі й діалогічного. Таке багатоаспектне явище, як дискурс, зумовлює існування термінологічної поліфонії, що не позбавляє наукові пошуки від труднощів, особливо при зівставленні різних мовних систем. Діалогічний дискурс має фазову організацію: початкову (фазу встановлення контакту між співрозмовниками; ядерну (фазу демонстрації тематики, цілей мовців та різні лексико-граматичні засоби, релевантні для вираження як тематики, так і інтенцій комунікантів; кінцеву (фазу завершення контакту - контакторозмикаючу). Початкова й кінцева фази діалогічного дискурсу ритуалізовані і за окремими розбіжностями претендують на універсальність. Аналіз ядерної фази спростовує існування думки, що чоловіки розмовляють переважно про пиво, жінок і футбол. Тематика їхніх розмов залежить від суспільних проблем, соціально-рольового статусу комунікантів, ступеня їхнього знайомства, інтересів, психологічних, когнітивних, політичних поглядів та інших чинників.

Перспективу наукових пошуків вбачаємо в подальшому дослідженні спірних питань сучасної лінгвістики. 


\section{References}

1. Backhaus, Helmuth. 1975. Liebling, schlaf nicht dauernd ein. München: Wilhelm Heyne Verlag.

2. Beile, Werner und Alice Beile. 1980. Sprechintention. Modelle 4. Textbuch. Bonn: Internationes.

3. Berkov, Vlamimir. 2002. Kultura dialoga. - Minsk: Novoe znanie.

4. Bezuhla, Liliya. 2020. Vid slova do dila: linhvoprahmatyka dyskursu. Vinnytsia: Nova Knyha.

5. Brinker, Klaus and Sven Sager. 2010. Linguistische Gesprächsanalyse.Berlin: Erich Schmidt Verlag.

6. Busch, Albert and Oliver Stasnschke. 2008. Germanistische Linguistik, 2. Aufl. Tübingen: Gunter Narr Verlag.

7. Chernyavskaya, Valeriya. 2013. Linhvistyka teksta. Linhvistika diskursa. Moskwa: Flinta; Nauka.

8. Deyk van, Andrianus. 2013. Dyskurs i vlast: reprezentatsyia dominirovaniya v yazyke i kommunikatsii. Moskwa: Knizhnyi dom «LYBROKOM».

9. Dyskurs yak kohnityvno-komunikatyvnyi fenomen: kolektyvna monohrafiya; za zah. red. Iryny Semenivny Shevchenko. Kharkiv: Konstanta, 2005.

10. Graefen, Gabriele and Martina Liedke. 2008. Germanistische Sprachwissenschaft : Deutsch als Erst-, Zweitoder Fremdsprache. Tübingen und Basel: A. Francke Verlag.

11. Gruhl, Hans. 1983. Fünf tote alte Damen. Germany: Rowolt Verlag.

12. Kessel, Katja and Sandra Reimann. 2008. Basiswissen Deutsche/Gegenwartssprache. Tübingen zbd Basel: A. Francke Verlag.

13. Kravchenko, Mykhailo. 2006. Integrativnoe, zhanrovoe i kontseptualnoe modelirovanie mezhdunarodnopravovoho dyskursa. Kyiv: Referat.

14. Myuller, Vitaliy. 2007. Velykyi nimetsko-ukrayinskyi slovnyk. Kyiv: Chumatskyi Shliakh.

15. Wahrig, Gerhard. 1997. Deutsches Wörterbuch. Gutersloh: Bertelsmann Lexikon Verlag.

Застровская София, Застровский Александр. Основные характеристики фазовой структуры диалогического дискурса. Статья посвящена выявлению характерных особенностей фазовой организации диалогического дискурса. Тщательно рассмотрены трактовки релевантных для данного исследования таких понятий, как Gespräch, Dialog, Konversation, Diskurs. Выявлены их общие признаки и отличительные особенности в соответствии с научными актуальными для современной лингвистики традициями. Пофазовый анализ диалогического дискурса позволил выявить как основные характеристики, так и разные причины, которые влияют на его процесс. Начальная (контактоустанавливающая) и конечная (контактозавершающая) фазы в основном ритуализованы, при этом, однако, допускают вариативность своего языкового/неязыкового/параязыкового оформления, особенно при сопоставлении телефонной и face-to-face коммуникации. Вариативность зависит прежде всего от социального статуса и ситуативной роли коммуникантов, а также психологических, когнитивных, семантико-прагматических факторов, которые влияют на успешность/неуспешность интеракции собеседников. Ядерная фаза диалогического дискурса демонстрирует тематику разговоров, мотивы, целеустановки коммуникантов, употребленные ими коммуникативные ходы (речевые акты) и лексико-грамматические средства ихнего выражения. Семантико-тематические признаки ядерной фазы диалогического дискурса обуславливаются пропозициональным содержанием. При этом доминантную роль играет предикат, выраженный глаголом соответствующей семантики в грамматических формах Indikativ i Konjunktiv, что зависит от типов речевых актов в коммуникативных ходах интерактантов. Тип употребления синтаксических структур свидетельствует об эксплицитности или имплицитности выражения речевых актов. Анализ эмпирического материала доказывает существование невербального выражения контактоустановления и контактоокончания фазовой структуры диалогического дискурса. Ядерная фаза, особенно в диалогах художественной литературы, может быть осложненной, где разные фазы диалогического дискурса перекрещиваются и повторяются. Анализ таких дискурсов обуславливает подключение к трактовке дискурса понятий с других традиций его исследования.

Ключевые слова: диалогический дискурс, фазовая организация, семантико-тематический, коммуникативно-прагматический, языковой/неязыковой/параязыковой.

Zastrovska Sofiia, Zastrovskyi Oleksandr. The Main Characteristics of the Phase Structure of Dialogic Discourse. The article deals with the identification of characteristic features of the phase organization of dialogic discourse. The interpretation of such notions as Gespräch, Dialog, Konversation, and Diskurs relevant to the achievement of the goal and objectives of this study is thoroughly considered. Their common and distinctive features are specified according to the scientific traditions of modern linguistics. The phase analysis of dialogic discourse revealed the main features and various factors influencing the process of dialogic discourse. The initial (contact initiation) and final (contact termination) phases are mostly ritualized, while allowing for variability of their verbal and nonverbal representations, especially when comparing telephone and face-to-face communication. The variability depends primarily on the social status and the situational role of the interlocutors, as well as psychological, cognitive, and semantic-pragmatic factors that affect the success/failure of their interaction. The core phase of dialogic discourse demonstrates conversation topics, motives and goals of interlocutors, the communicative moves (speech acts) and lexical and grammatical means of their expression. Semantic-thematic features of the core phase of dialogic discourse are determined by the propositional content. In this case the dominant role is played by the propositional predicate, which is expressed by the verb of the corresponding semantics in the grammatical forms of Indikativ or Konjunktiv, depending on the type of speech acts in the communicative moves of interlocutors. The type of syntactic structures indicates the explicitness and implicitness of the expression of speech acts. The analysis of empirical material proves the existence of non-verbal expression of contact initiation and contact termination in the phase structure of dialogic discourse. The 
core phase (especially in fiction) can be complicated, where different phases of dialogical discourse overlap and repeat. The analysis of such discourses leads to the use of notions from different traditions of discourse study to interpret discourse.

Key words: dialogic discourse, phase organization, semantic-thematic, communicative-pragmatic, lexicalgrammatical, verbal, nonverbal.

DOI: https://doi.org/10.32782/2410-0927-2020-12-15

УДК 811.111 '367.623

Наталія Канонік

\section{КІЛЬКІСНЕ СПІВВІДНОШЕННЯ ЗНАЧЕНЬ ПРОСТОРУ Й ЧАСУ В СЕМАНТИЧНІЙ СТРУКТУРІ ПРИКМЕТНИКІВ СУЧАСНОЇ АНГЛІЙСЬКОЇ МОВИ}

У статті проаналізовано просторово-темпоральні орієнтації прикметників сучасної англійської мови. Хоча вивченню одиниць 3 темпоральною та просторовою семантикою присвячено багато праць, зокрема дослідженню лексичних одиниць поля часу англійської мови в системі мовних засобів та зафіксовані спроби лінгвістів охарактеризувати всі мовні засоби з просторовою семантикою, проблема залишається актуальною та відкритою для досліджень. Метою даної статті є встановити кількісне співвідношення простору та часу в мовному вираженні, а саме просторово-часовий аспект у лексико-семантичній системі на матеріалі прикметників сучасної англійської мови, що і $є$ новизною дослідження. Для досягнення мети необхідно встановити точку перетину лексикосемантичних полів простору й часу в семантичній структурі прикметників сучасної англійської мови, виокремити прикметники, у яких перетинаються семи просторовості й темпоральності, дослідити взаємодію сем простору й часу, встановити співвідношення простору й часу в семантичній структурі прикметників у кількісному плані.

Основним поняттям при аналізі та описі семантики з'явилося ствердження системності слів мови, яке і знайшло своє втілення в методі дослідження лексико-семантичного поля. Польовий принцип, перш за все, базується на виділенні ядра та периферії досліджуваних мовних одиниць. Саме через периферійну зону може бути встановлений зв'язок різних полів, які перетинаються і входять одне в одне, що і надає лексико-семантичній системі мови не лише міцну внутрішню цілісність, але й мобільність та гнучкість.

Проаналізовано 113 просторових прикметників та 117 темпоральних прикметників, представлених як певний результат пізнавальної діяльності людини, що виокремлює у своїй свідомості уявлення не лише про категорії простору й часу реального світу, але й про їхні ознаки. Виявлено, що 26 прикметникам властиві семи і простору, й часу. 18 прикметників складають ядро та несуть максимальне функціональне навантаження. полісемія.

Ключові слова: простір, час, просторовість, темпоральність, лексико-семантичне поле, мікрополе, сема,

Постановка наукової проблеми та ії значення. На лексичному рівні системність виявляється передусім в існуванні певних лексичних цілісних утворень, які виділяються 3 масиву елементів лексичного складу мови, і зв'язків між членами цих лексичних утворень [5; 9]. Слова в мові неоднорідні, а лексичні значення слів, які можуть належати до певного лексичного складу, здатні взаємодіяти та перетинатися зі значеннями слів інших класів [11, с.411]. Як зазначав Л. В. Щерба, лексика кожної мови в даний момент часу є певною системою, а слова кожної мови утворюють систему і зміна їх значень цілком зрозуміла лише в середині такої системи $[12$, с. 89]. Загальнотеоретичними проблемами та розробкою конкретних методів практичного дослідження лексики як системи займався також В. В. Виноградов, який стверджував, що слова та їх значення в тій чи тій загальнонародній, загальнонаціональній мові утворюють єдину та загальну для всіх членів суспільства систему. Він виділив такі особливості лексико - семантичної системи: 1) структурною основою лексико-семантичної системи мови $\epsilon$ основний словниковий фонд; 2) зміни в словниковому складі не ламають лексичну систему мови, не знищують іï основний словниковий фонд, його структурну основу, також і лексикосемантичні системи не замінюють одна одну, як вартові, а взаємопроникають. Можливість перетину окремих полів є важливою характеристикою лексичної системи та здійснюється завдяки декільком семемам, які розміщені на перетині різних груп полів [3, с. 120].

Отож, мета цієї розвідки - встановити кількісне співвідношення простору та часу в мовному вираженні, а саме просторово-часовий аспект в лексико-семантичній системі на матеріалі прикметників сучасної англійської мови.

(C) Канонік Н., 2020 